\title{
A NOT SO PERFECT PEACE: A HISTORY OF CONFLICT ON IFALUK
}

\author{
Laura Betzig and Santus Wichimai \\ University of Michigan Yap State Senate
}

\begin{abstract}
Many accounts of the Caroline Islands have called the people in them non-violent. This paper uses early ethnographies, more recent ethnohistories, and new recollections on the part of the people of Ifaluk to reconstruct the extent of conflict on Caroline Islands and between them. Culture on Ifaluk in precontact times, and even in recent times, was violent in many respects. The evidence presented here contradicts several earlier arguments, among them: that the balance in the tribute relationship with Yap favoured outer islanders; that the balance in the tribute relationship between Ifaluk chiefs and commoners favoured commoners; and that sorcery and aggression were rare or absent on Ifaluk. Legends of wars between Ifaluk and other islands are also retold.
\end{abstract}

'... We behold those of the low islands enjoying the most perfect peace'

Lütke

Visitors to the Caroline Islands in this century have been impressed by the apparent lack of conflict (e.g. Krämer 1937; Damm et al. 1938; Lessa 1950a, 1950b, 1962, 1966; Spiro 1950; Gladwin and Sarasson 1953; Bates 1956; Burrows and Spiro 1957; Bates and Abbott 1962; Alkire 1965; Lutz 1980, 1982, 1988; Montagu 1976). On Ifaluk, an atoll near the center of the Caroline archipelago, that impression has been consistent. Since Sarfert stopped for twelve days in 1909, Ifaluk has been visited by three ethnographic expeditions. Burrows and Spiro (1957), along with other members of the Coordinated Investigation of Micronesian Anthropology, witnessed only misdemeanors by 'four dogs and one madman' (p.195) during a six months stay; Lutz (1982) found a single incident of shoulder-shoving the most violent act in a year; and Betzig, Turke, Rodseth and Harrigan, in six months of combined observation, never saw physical violence among adults, and saw adults punish children physically only twice.

As in many other parts of the world, however, the impression of pacifism has grown with Western domination. Although the Portuguese captain Dioga da Rocha got a friendly reception on Ulithi (Lessa 1975), plenty of successors were robbed or slain in the Carolines (see Hezel 1983). On the larger islands, where Westerners' visits were sometimes protracted, violent conflict is said to have been endemic (e.g., Lessa 1962; Hezel 1983). Visits to the atolls were, on the other hand, almost invariably short; and violent conflict, though it was recounted, was seldom seen. Still, Cortyl, Duberron and Cantova, the first missionaries to try to live in the low islands, were probably killed on Sonsorol and Ulithi (Hezel 1983). Early accounts of aggression on Caroline atolls are as consistent as accounts of its absence are now. 
The early conflict continues to be overlooked. In the Carolines, as in other cultures, conflict took place both within and between groups, and among equal and unequal powers. This paper looks at the nature and extent of conflict both on Ifaluk itself and between Ifaluk and other islands. These include:

1. Thetribute relationshipbetween Ifaluk and Yap;

2. Warfare between Ifaluk and other Caroline islands;

3. The tribute relationship between Ifaluk commoners and chiefs; and

4. Conflict among individuals and villages on Ifaluk itself.

\section{CONFLICT BETWEEN IFALUK AND OTHER ISLANDS}

The people of Ifaluk communicated with the outside world by canoe. Caroline Islanders (see Fig. 1) sailed intermittently, and often accidentally, to the Philippines, the Marianas and the Marshalls (e.g., Lessa 1950a; Gladwin 1970; Hezel 1983). They had sustained communication with islands inside the 'Yapese Empire', involving an important trade relationship with nearby atolls (Alkire 1965), and a tribute relationship with Yap (Lessa 1950a). Wherever there is contact there is the potential for conflict. Though it is accepted that legendary wars with nearby atolls in fact took place (e.g., Burrows and Spiro 1957), it is less certain that wars between Yap and outer islands reported in legends ever happened (e.g., Lessa 1950a; Burrows and Spiro 1957; Lingenfelter 1975).

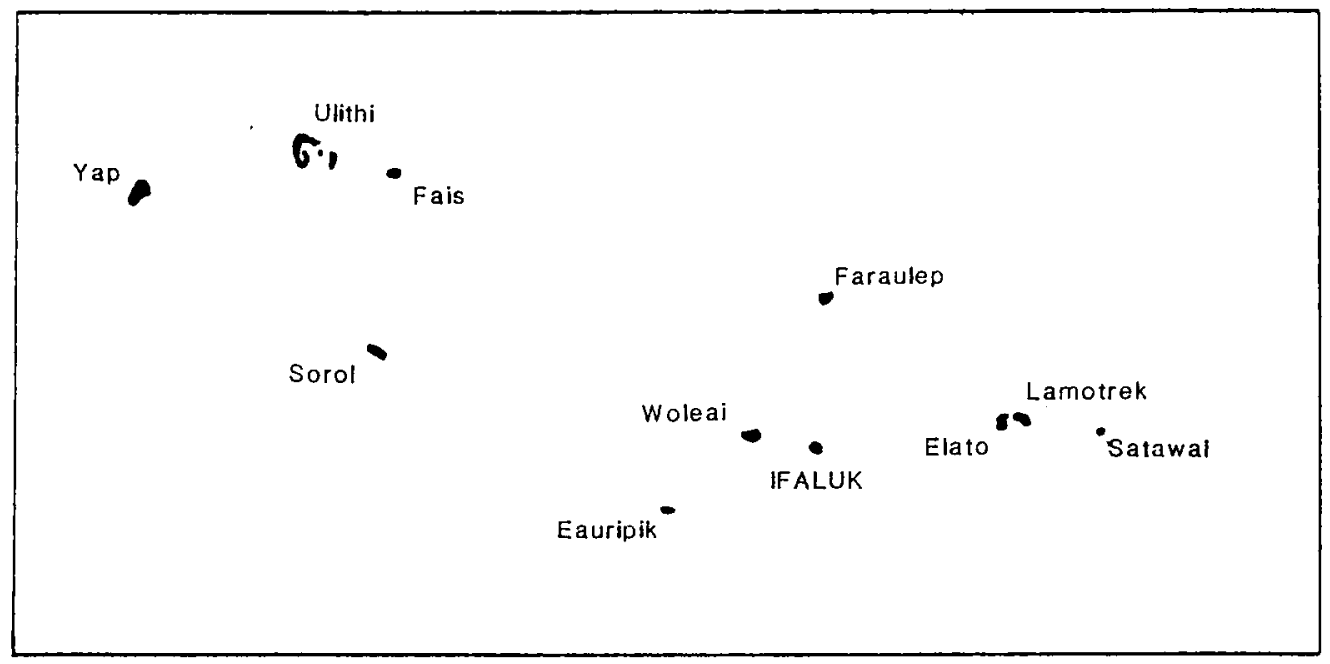

Figure 1: The Western Caroline Islands.

\section{Conflict Between Unequal Powers: Ifaluk vs. Yap}

Whether or not violent conflict occurred between Yap and Ifaluk, there is plenty of evidence of conflict of interest. Lessa, who reconstructed the Yapese Empire, said that two of three kinds of 'exchange' between low islands and Yap flowed exclusively from the former to the latter, and that the third was more reciprocal. At the same time, he concluded that 'it would seem that the balance is really in favour of the tributary islands' (Lessa 1950a:43; see also Lingenfelter 1975:153). Such a balance, tipped on the side of subordinates, would be consistent with some theories (e.g., Sahlins 1972:205). It would be inconsistent with other 
theories (e.g., Alexander 1979), and with the facts in many societies (e.g., Betzig 1986), including the facts on Ifaluk itself (Betzig 1988a; see below).

Until the Japanese put an end to long distance sailing in the second decade of this century, every two or three years one Ifaluk canoe would join canoes from other outer islands at Ulithi, and sail on to Yap. They would carry tribute (pitigil tamol) and religious offerings (mepel), including lava lavas, sennit rope, pandanus sails, tobacco, coconut oil and coconut candy (Lessa 1950a:42); they may also have offered their overlords labor (Burrows and Spiro 1957:9; Lessa 1950:51; but see Lessa 1950a:46). None of these favors would be returned. For the third form of gifts outer islanders brought (sawei), however, they would be given food to eat and a place to stay, and they would sail home with gifts of fruit and vegetables, turmeric, grass purses, combs, clay for pots, bamboo and occasionally timber. Each of these may later have been returned in kind, when Yapese hosts became outer islanders' visitors (see Lessa 1950a). ${ }^{1}$

Other 'exchanges', possibly even more important, also were not reciprocal. When on Yap, Ifalukese and other outer islanders owed their hosts an elaborate etiquette. They were required to bow low and apologize 'Soro!' in passing any Yapese man, woman, or child; and they were strictly forbidden to make themselves attractive, by using turmeric as a cosmetic, chewing betel nut to make their lips red, or wearing leis or coloured cloth. Most importantly they were forbidden to court or marry Yapese women, except those of the lower caste (de Beauclair 1964). All of these patterns are common in stratified societies (e.g., Betzig 1982, 1986). According to Lessa, many women from low islands migrated to Yap 'where they have married and settled down. Their children have been adopted into the lineages of their sawei, and ... they have attained positions of headship'. On the other hand, 'on account of the caste restrictions which apply to males from other islands, the number of men who have migrated to Yap is far less. [Low islanders] ordinarily avoid marriage to any Yapese women whatever' (Lessa 1950a:45). ${ }^{2}$

If men of Yap 'consumed' more women that did men of the low islands, they must also have consumed more resources to support those women and their children (cf. Chagnon 1979). Though women may have the potential to be self-supporting in some societies, men in every known culture provide some services for them (e.g., Barry and Schlegel 1982; Hurtado 1985; Betzig 1991); Yap is no exception (e.g. Turke 1985). Those services must have increased with the numbers of their wives. More importantly, the services men offered to children must have increased with the number of their childbearing wives. The children women bear entail considerable economic costs; they depend on adults for food, direct care and protection for many years (see Turke 1989). Detailed, quantitative and qualitative evidence from Yap and Ifaluk suggest that resources tend to flow down the generations, from parents to children, at all ages (ibid.).

Where, then, did Yapese men get the extra resources to provide for the women they took from other Islands? The possibility that some of those resources may have come from tributary islands is suggested by an Ifaluk song about a typhoon: 'The people of Yap will be sorry to hear of this. There will be nothing left for them to take' (Burrows and Spiro 1957:9). It is also suggested in Cantova's eighteenth-century report that, according to low islanders, the Yapese venerated crocodiles: 'It is under the guise of this crocodile that the Demon exercises over these people a cruel tyranny. A group of enchanters is found among them: they have contact with the evil spirit and with his help they secure sickness and even death for those whom they wish to undo' (Cantova 1728:231-2). 
To the extent that, overall, 'the Carolinians invariably received greater economic benefits from the exchange than the Yapese' (Lingenfelter 1975:153; cf. Lessa 1950a:43), any sanctions needed to maintain the tribute system should have come ultimately from the outer islands. That they did has never been suggested. To the extent that the exchange was equal, conflict should have been minimal, and sanctions should have been unnecessary on either side. To the extent that the balance was, after all, on the overlords' side, any sanctions should have come from Yap. That they did has been generally agreed upon (e.g., Lessa 1950a; Lingenfelter 1975). What sanctions the Yapese used is, though, unclear. Lessa (1950a) emphasizes that they threatened supernatural reprisals; Lingenfelter (1975:153; see too Lessa 1962:362) suggests that ' $w$ arfare is also reported in the legends, but the extent to which tribute is related to conquest cannot be documented'.

Violent resolutions to conflict between equal powers tend to take the form of war, while violent resolutions to conflict between unequal powers tend to take the form of law (Betzig 1986). If the Yapese were capable of mounting a much larger force against the people of Ifaluk than could be returned, then aggression was probably less likely than a laying down of arms (cf. Maynard Smith and Parker 1975). The threat of force should have been sufficient to resolve conflicts in favor of the people of Yap. Following, perhaps, an initial conquest, violent conflicts between Ifaluk and Yap should have taken the form of punishment of offenders breaking the inter-island 'law' of tribute offering. It seems much less likely to have taken the form of war, as it did among equal Caroline powers, including villages on Yap itself (e.g., Lingenfelter 1975), and among the outer islands (e.g. Burrows and Spiro 1957). What actually happened must, though, remain a matter for speculation.

\section{Conflict Among Equals: Ifaluk vs. Nearby Islands}

Many early descriptions of the Carolines mention weapons, among them spears, clubs and slings (Lesser 1962). Surprisingly, Captain James Wilson, who is credited with the first European sighting of Ifaluk on October 27,1797 , is supposed to have said of the Western Carolinians that

they handle their boats with great skill and sail without fear from island to island. From this fact we concluded that hostilities and wars were rare and free movement would thus be possible; this idea is substantiated by the lack of weapons of the islanders, who have none, with the exception of a sling (Krämer 1937:191).

Though Wilson and crew stopped to trade on Ifaluk, they did not stay there. Sarfert, who did, noted in 1909 that 'in former times there were a good many wars (fiteg), and today the natives fight with spears, sticks and knuckle dusters of sharks' teeth (rajaras). They hurl stones with their hands. No bows and arrows are used' (Damm et al.1938:187). He collected barbed spears and clubs with points or small blades at both end(Burrows and Spiro 1957:17). Though Sarfert complained that, almost a century ago, people on Ifaluk ' did not know much about ... the history of the island as he had expected' and had 'forgotten a great many of [their] old beliefs' (Damm et al. 1938:1), he did say he saw 'a good many large scars' (p.12), the causes of which admittedly might have been accidental rather than intentional.

Descriptions of warfare and weapons on nearby islands corroborate Sarfert's impressions. Cantova (1728:242-3), the missionary eventually killed on Ulithi, mentioned warfare in the short ethnography he wrote in 1722 after spending eight months with 24 Woleaian castaways on Guam. According to Cantova, 'their only weapons are stones and spears tipped with fish-bone'. Kotzebue saw a Woleaian lance (tilleg) and sling (kaul) in 
1817 (Krämer 1937:270). Though Krämer failed to find spears or clubs on Lamotrek and Woleai (ibid.), he did collect a knuckle-duster 'with fish spines', and reports that though

warfare is rare among the natives of the island group ... it must have been different in the past, at least as far as outside affairs were concerned when the king of Lamotrek ... ruled over extensive territories. We heard not too long ago that Ifaluk had attacked the people of Lamotrek because the latter had killed the crews of two of their canoes (Krämer 1937:116).

Legends of this attack were still recalled on both Ifaluk and Lamotrek at the time of Burrows's and Spiro's visit. Stories of wars with Lamotrek, Faraulep and Woleai were all recounted to Burrows and Spiro in 1947. They were retold to us in 1987. The essence of each story is the same: the men of Ifaluk outwit, and outmatch, men from the other islands; they then exterminate the native population man, woman and child; and finally they repopulate the islands with members of Ifaluk clans. The versions of each of these legends recalled to us are included in an Appendix at the end of this paper.

These legends account for the resettlement of four out of five Western Caroline atolls which share with Ifaluk both sibships and dialect (see Lessa 1980). These four are Woleai, Faraulep, Elato and Lamotrek. Only Eauripik is not accounted for. Of Eauripik, Burrows and Spiro's informant, Totogoeiti, implied but did not say that people from Ifaluk had settled it (Burrows and Spiro 1957:18). According to our informant, Tarmai, a man from Gilman municipality in Yap, who had married into Woleai, went with his family to repopulate Eauripik after the native population was wiped out by a typhoon. Though there is no warfare legend about Eauripik, 'generals' are supposed to have been recruited from there to fight wars on other islands. This is interesting. Since Eauripik is substantially smaller than its neighbors, it is doubtful that it could successfully have waged war on its own. In Western Caroline conflict, Eauripik may have been essentially an island of mercenaries. ${ }^{3}$

Assuming, then, that it took place after all, how frequent was Ifaluk war? Lessa (1962:352) suggests that warfare was more likely in the high islands, which had greater wealth and population, and less likely on low islands, which were relatively poor and small. The costs of travelling across the distances involved must have mitigated against the frequency of war among the low islands, if not on the atolls themselves. Alkire (1965) has played up the importance of economic ties among these atolls, especially in the event of typhoons; this too may have mitigated against the frequency of war. On the other hand, recent evidence from several small, tribal societies suggests that homicide rates have been much higher than in the modern U.S.; these 'homicide' rates include killings both within societies and between them in war (Knauft 1987: Table 2). And it might be argued that conflict will increase, rather than decrease, as resources become scarce (e.g. Firth 1959; see too Maynard Smith and Parker 1976).

Finally, whatever its frequency, what was the motive for Ifaluk war? The comparative evidence on this point is consistent: desire for women may be a nearly universal cause for war (e.g., Darwin 1871:871; Chagnon 1979; Betzig 1986). Women are especially likely to be mentioned as a motive where resources are poor (Mason and Wrangham 1991). Evidence from high Caroline Islands, including both Yap and Truk, suggests that women sometimes motivated warfare (e.g., Lingenfelter 1975:173; Krämer 1932:268-9). All of the legends from Ifaluk recounted by Totogoeiti and Tarmai, however, contradict such an inference. In every legend the vanquished are exterminated man, woman and child. This is especially puzzling since, like most people throughout history (e.g., Murdock 1967; Betzig 1986; Low 1988), pre-Christian Carolinians practiced polygyny (e.g., Lessa 1962:364), with chiefs 
having a right to several wives (Cantova 1728; Burrows and Spiro 1957:302). The most obvious spoil of Ifaluk wars was another chronically scarce commodity: land. The conclusion that land was a motive for individual warriors may be inconsistent, though, with both Totogoeiti's and Tarmai's versions of repopulation on Tamotrek, and with Totogoeiti's version of repopulation on Woleai, in which Ifaluk chiefs, like Noah, sent forth representatives from every clan. It is not consistent with Tarmai's version of Woleai's repopulation by the warriors themselves, which he offered only after our surprise that a Saufelachig chief would offer land to men of other clans.

\section{CONFLICT ON IFALUK}

On Ifaluk itself, where the absence of aggression has been so consistently admired (e.g., Burrows and Spiro 1957; Lutz 1982), disputes over land are chronic. This situation is common in the Carolines (e.g., Alkire 1974; Lingenfelter 1975). Conflict over fruits of the land has also been frequent enough on Ifaluk to prompt continual chiefly admonitions against it for the past century at least (e.g., Damm et al. 1938; Burrows and Spiro 1957; Lutz 1980). There is no question that conflicts of interest exist on Ifaluk. The question is, how are they resolved?

\section{Conflict Between Unequal Powers: Chiefs vs. Commoners}

Politics in all Caroline Island societies, high islands and atolls, revolve around a single principle: rank. Social relations in the low islands were never, of course, as hierarchical as they were on Yap (e.g., Lessa 1950b); but even in the tiny atoll cultures of the Carolines chiefs have been elevated, both literally and figuratively, to a surprising extent. As late at 1947, Burrows and Spiro (1957:179) found that on Ifaluk

rank is so highly valued and respected that it stands out as one of the master-values of this culture. A hierarchy of rank runs through the whole society. In it each individual has a place; and standards of good behavior require each to show by his conduct that he 'knows his place'.

By most indications, the importance of rank was even greater in the past. According to Cantova's castaways, Caroline atoll chiefs were distinguished by dress (wearing 'a sort of robe slit at the sides which covers their shoulders and chests and reaches to their knees', while other men wore no more than a loincloth), by other adornments ('the nobles paint their bodies and pierce the lobes of their ears, to which they fasten flowers, aromatic herbs, bits of coconut or even glass when they can get some'), and by pomp in burial rites (Cantova 1728:198, 228). What is more:

These Tamoles [chiefs] let their beards grow quite long to win themselves more respect; they command with authority, speak little, and affect a grave and serious air. Whenever a Tamol gives an audience, he appears seated on an elevated platform; the people bow to the ground before him, and those who approach him from a distance walk with their bodies bent until their heads touch their knees - they remain in this posture to the moment when they are close to him - they then prostrate themselves flat on the ground with their eyes down and there receive his commands with deep respect.

When the Tamol dismisses them, they go off with their bodies bent over just as when they came and do not rise until they are out of his sight. His words are tantamount to oracles which they revere; his orders are obeyed blindly to such an extent that the 
people kiss his hands and feet when ever they ask some favor. The run-of-the-mill homes of these islanders are only small and very flat huts covered with palm-leaves. Those of the Tamoles are made of wood and are decorated with such paintings are they are able to produce (Cantova 1728:235-6). ${ }^{4}$

There are now, and traditionally have been, five major matriclans on Ifaluk. They are: Hofalu, Saufelachig, Mengaulufach, Chapifelu and Sauwel. Historically, the highest ranking man of Hofalu, the highest ranking clan, has been called ubut or 'king', and has had final authority in all decisions concerning the whole atoll." The highest ranking men of Saufelachig and Mengaulufach, the second and third ranking clans, have been called tamol or 'chief', and have sat together with the ubut in determining atoll affairs. Chiefs of Chapifelu and Sauwel, the fourth and fifth ranking clans, have acted as advisors to these three, performing special functions as messengers and magicians, respectively (Betzig 1988a). This structure was still intact in form, and to some extent in function, as late as 1987.

Like the hierarchical relations between Ifaluk and Yap, those between commoners and chiefs on Ifaluk itself have involved resource transactions, principally in one direction. Far from being covetous, Ifaluk chiefs are said to have been generous, at least in this century. This is consistent with what has been written about the relationship of the people of Yap to their outer island subjects (e.g., Lessa 1950a:43; Lingenfelter 1975:153), and about chiefs in a number of other Pacific cultures (e.g., Sahlins 1972). Less than half a century ago, Spiro (1949:16-7) wrote of Ifaluk chiefs that 'though, theoretically, their power is absolute, I saw not a single instance of abuse of this power, in the form of demanding of property or gifts or women'.

Demanding or not, however, chiefs on Ifaluk have received more than an equal share of all these things. They have had privileges in property: Ifaluk chiefs, like chiefs on nearby low islands, still have the last word over the use of land and water resources, and may have first rights over larger plots (especially Alkire 1974). They have also been given gifts: according to Cantova (1728:237-8), iron from foreign ships belonged by law to chiefs, who used it to make tools which they 'rented' out at high rates. Gifts to chiefs have included the atoll's indigenous goods as well. Chiefs of high ranking clans still get almost twice as many fish in redistributions following collective catches (Betzig 1988a); the chief of Saufelachig clan is still given tribute in fish, palm wine and breadfruit twice every year from men in Falachig village, which he may redistribute among the members of his clan; ${ }^{6}$ and all clan chiefs retain the right to do less physical labor than commoners (Betzig and Turke 1985; Betzig 1988a). Historically, members of highest-ranking Hofalu clan claimed exclusive rights to turtles and to giant groper, both of which may amount to hundreds of pounds of meat; members of Hofalu still retain the former right. Members of second-ranking Saufelachig clan had, but no longer have, exclusive rights to yellowfin tuna, which come in schools of thousands, ranging from about 10 to 400 pounds apiece, usually during the trade-wind season (Betzig 1988a). All of these fish can be preserved by smoking. Finally, Ifaluk chiefs have, traditionally, been given more than an equal share of women: again, chiefs had a right to several wives (Burrows and Spiro 1957:302; Lessa 1962:364). Cantova (1728:232) suggested that some atoll chiefs might have had as many as nine at a time. Polygyny on Ifaluk was once 'looked upon as a mark of honor and distinction' (ibid.), as it was almost everywhere else (Betzig 1986). Each of these advantages suggests that the balance in the tribute relationship between Ifaluk commoners and chiefs was not on the subordinates' side (Betzig 1988a). 
Ifaluk chiefs have, though, fulfilled a number of obligations. First among them has been making their subjects behave as equals. Chiefs constantly admonished commoners, both in public and in private, not to lake labor or resources from one another. Second, chiefs have controlled public affairs. They still order the construction, repair and clean-up of public buildings and grounds and okay the construction of private projects. Third, chiefs have ordered, and still order, communal fishing expeditions. Last, chiefs were traditionally called on to resolve major disputes (see tooSarfert in Damm 1938:81). For generations, Ifaluk chiefs have called together all atoll men several times every year and repeated the same admonitions, incorporating all but the last of these functions. Chiefs have told the women of Ifaluk to work hard cultivating their own taro, and not to steal taro from other women; they have warned Ifaluk men never to shirk their responsibility to respond to the call for collective fishing, and never to take communally caught fish before it is redistributed; and they have ordered both women and men to work together on public construction and clean-up jobs (cf. Burrows and Spiro 1957:189-93). Undoubtedly to some extent, such chiefly actions have reflected the interests of commoners, and to some extent they have reflected the interests of chiefs. That Ifaluk should be well kept, that no one should shirk their communal work, and that no one should steal, should be in the interests of all. At the same time, to the extent that chiefs contribute less labor, but get more of the spoils of others' labors, these ends should serve them best (Betzig 1988a).

That these and other perquisites amply reimbursed holders of chiefly office is suggested in Lessa's (1962:353) conclusion that, according to early Caroline documents, 'causes of discord ... often seemed to stem from political ambition'. They are also consistent with the modern impression that people resented these chiefs, gossiped about them, and privately insulted them. ${ }^{7}$ Though conflict according to rank must have been greater on Truk, it is astonishing to note that human sacrifices of men, women and children would be made there following the death of a king (in Lessa 1962:367).

Both to preserve their own advantage, and to benefit all of their subjects, Ifaluk chiefs sometimes imposed sanctions. Traditionally, these included the penalty of death. In former times, chiefs had the authority to kill their subjects, following a consensus reached by the chiefs in council. Sorcery was the method employed. ${ }^{7}$ Compensation would be great, in lava lavas, lengths of sennit rope, and even pieces of land, as sorcerers (tausausau) would inevitably die for having killed, though at an indeterminate time. So, however, would be the returns. By burying various herbs and stingray stingers about their houses, sorcerers are supposed to have brought death upon offenders against chiefs - sometimes including, presumably, offenders against the common good. Sorcery is mentioned in early Caroline atoll accounts (e.g., Cantova 1728), but it has been covert or intermittent in recent history (see Spiro 1952 and Burrows and Spiro 1957:219-20). Nevertheless, Ifaluk sorcerers in this century are said to have wiped out one entire household and to have attempted to wipe out another.

In the first case, starting in German time (early in the century, before the first World War), chiefs paid one sorcerer to wipe out a household, on a (low-ranking) Bwol clan estate called Matechal.' This necessitated killing around seventy people, mostly young men. The sorcerer finished the job by around 1940 . These young men were punished for repeatedly ignoring admonitions not to disturb communal fishing expeditions. They stole fish before they were brought to shore and redistributed them equally to every person in every household, with the exception of chiefly households (e.g., Betzig 1988a) 
In the second case, not long before the first, chiefs hired a sorcerer to wipe out another household, this one belonging to (highest-ranking) Hofalu clan, on an estate called Hepalgol ${ }^{7}$ This was another large household, again with many young men, and again the offense was cheating during communal fishing. In this case, though, the offenders survived, because while the sorcerer was burying his piles of herbs on the estate, he accidentally stepped on one, cursed and gave himself away. This sorcerer died about a month later as a result; members of the household who moved to Falpengag estate, are still alive.

It is interesting that in both of these cases the offence for which the death penalty was sought - not just for the offenders, but for their entire households - was cheating on the system of communal fishing and redistribution. Clearly, sharing is a fundamental ethic on Ifaluk (see e.g., Burrows and Spiro 1957), regardless of who reaps the biggest benefit. Other offenses for which chiefs are supposed to have hired sorcerers to perform executions are murder and incest within the clan; but no specific case of either is remembered.

Others have suggested that the death penalty might also have been brought about by exile (Cantova 1728:236), and that confiscation of all property, including clothes, canoes and even land, might follow a murder (Damm 1938). Besides these penalties, chiefs had the power to inflict a number of punishments, including warnings, fines and property destruction or confiscation, for different offenses. ${ }^{7}$ Warnings of an anonymous sort were obviously the point of every island meeting; occasionally these 'seemed to be directed at one or more specific malingerers' (Burrows 1949:145). Sarfert in 1909 noted pecuniary punishments for a number of offenses (Damm 1938:82; see too Burrows and Spiro 1957:194-5). In each, a specific number of 'cloths' (lava lavas), canoes, or both were levied for injuries ranging from loss of a finger to loss of both eyes, arms, or legs (ibid.). None of those punishments is remembered as inaccurate; though fines are much higher now, the difference might be due to inflation brought about by the introduction of modest cash incomes for government work and copra production (see e.g., Betzig 1988a).

In the past generation, chiefs have inflicted penalties directly on offenders twice. ${ }^{7}$ In the first case, the man who would eventually succeed to chieftainship of Saufelachig was caught leaving a bonito in a canoe when communally caught fish were being counted. Again, the strong sharing ethic on Ifaluk brought an equally strong sanction: chiefs ordered all of his crops cut down! No breadfruit or coconut trees were tackled ('that would take a chain saw all day!'); but all of his papaya and banana, and much of his matrilineage's taro, were destroyed. Ordinarily, this penalty is supposed to have followed a second offense. In the second case, the man who had been elected to represent Ifaluk in the Yap State Senate arrived for a visit on Ifaluk with two bottles of whiskey, one of which he kept for himself and the other of which he gave away to the government-paid health care aide. Chiefs just a short while before had imposed a ban on alcoholic beverages, in the wake of the Hofalu chief's death. On Ifaluk, as elsewhere, ignorance of the law is no excuse; for breaking the ban, the senator was fined two large coconut leaf baskets full of lava lavas, at about ten lava lavas per basket, plus about two thousand feet of sennit rope. This fine, along with the one levied against the health care aide, went to the chiefs' council, from which it should have been redistributed to each village.

In only one remembered case did commoners ever effect a verdict against a chief. In that case, about a hundred years ago, a nephew of the Hofalu chief killed him with a bonito spear, piercing his legs and belly. ${ }^{7}$ This chief, who already had two wives, was having sexual relations with a would-be third, a member of his own clan. He was, in other words, breaking a strict clan law against incest. Following a meeting of the Hofalu clan, it was decided the 
chief must give his life for his action. His nephew, one of his possible successors, was chosen to do the job.

With this exception, then, Ifaluk chiefs themselves had the power to resolve conflicts, both in the interests of their subjects and in their own interests. In other words, rank relations on Ifaluk seem to have paralleled those between islands. Property, gifts and women have flowed from commoners to chiefs; aggression flowed in the opposite direction. The content of all but the last of these cases suggests that infractions against the sharing ethic were particularly likely to be punished (cf. Burrows and Spiro 1957), and that infractions were most likely to be by young men. At the same time, the fact that those punishments were necessary at all suggests that the ethic did not always prevail.

\section{Conflict Among Equals: Commoners vs. Commoners}

Among equals conflicts of interest could be resolved in three main ways. They were: through talk, through sorcery and through personal violence." Arguments even now can be over matters as apparently trivial as who the best fishermen are. Most commonly, however (cf. Lessa 1962, 1966; Alkire 1965, 1974), they are over land. Differences of opinion over where boundaries lie between estates, around taro swamp plots and on the reef, are endemic in the Caroline Islands. Quarrels still come up; they sometimes get heated enough to provoke shouting. Historically, when antagonists became really angry, one or the other would cross onto the disputed plot and cut down an adversary's trees by way of stating a claim. At that point, Ifaluk's golas (variously translated as 'bodyguards', 'village police' and 'village chiefs') would intervene, and gather together elders of both clans to try to determine whose land was whose. Though golas are remembered to have settled minor disputes themselves, important conflicts are supposed to have been referred to the council of clan chiefs (cf. Sarfert in Damm 1938:81). It was the golas' job to inform the tamol, and especially the ubut, of commoners' disputes; they also informed commoners of decisions those chiefs reached.

Second, individual differences could be resolved by recourse to sorcerers. Lessa (1961) recounted six cases of sorcery involving inhabitants of Ifaluk, along with an informant's insistence that the natives of Ifaluk and 'Satawan-itu' were the most skilled magicians of all (cf. de Beauclair 1963). Even now, sorcerers can be hired on Ifaluk, or recruited (as they often were in the past) from Woleai, to help make canoes stray off course. ${ }^{7}$ For a substantial fee, usually paid in lava lavas, sometimes in metal and other valuables, an individual or his clan could hire a sorcerer to kill an enemy by, for instance, wrapping herbs in fibers from the bottom of a coconut palm and securing them to the victim's sailing canoe. In one specific case, about a century ago, Woleaian men are supposed to have hired a sorcerer to kill Ifaluk men who used their paint on a sailing canoe. The Ifaluk canoe drifted off course on its way home and the Woleaian sorcerer was blamed.

Finally, there is evidence that individual differences were not infrequently resolved by violence. Traditionally, there has been curfew on Ifaluk at dark. After about nine o' clock, Ifaluk men, usually two and always more than one, would be posted at both ends of every Ifaluk village. ${ }^{7}$ These men would be the golas themselves, or representatives they had picked; they were supposed to have been young and strong; and their identity, like that of sorcerers, was supposed to have been a secret. It was assumed on Ifaluk that, after sundown, anybody out without a torch was either acting as a sorcerer or 'looking for women'. It was the job of these guards to defend the villagers against these trespassers. Anybody who tried to cross into a village without a light after dark was to be killed. 
Golas always carried shark tooth knuckle-dusters (rajaras), and hardwood spears about a yard long and sharpened at both ends (tilleg). ${ }^{7}$ Two other kinds of weapons used both in wars against other islands and on Ifaluk itself might be carried. These included the hardwood sticks still used to pound coconut husk fiber, unsharpened and only about a foot long (haingie), and hardwood knives, about two to two and a half feet long, sharpened like daggers at both ends (pezhosh). Golas may also have used a sling (kaul; see Krämer 1937), and have practiced a form of martial arts (Lessa and Valez-I 1978). Every man on Ifaluk could keep all of these weapons for his personal use, and did. Should an intruder get past the golas and trespass on his land, looking, most likely, for a woman, but also possibly for coconuts, taro, or valuables including metal, a man was at liberty to kill him without asking questions.

One such case of trespass is still recalled; the grandson of the man who got hurt is still alive. ${ }^{7}$ This man entered a village without a torch, guards went first to fetch reinforcements, then chased him across the island, and finally cut him across the neck with an axe. The victim's brother rescued him, first taking the axe from his attackers, and then hauling his wounded brother all the way across the windward side of Falachig islet to Falalop (that is, from one of Ifaluk's inhabited islets to the other). This man is said to have been after a girl.

Taking so much trouble to have sexual intercourse with a woman runs counter to much of what has been written about Ifaluk over the last fifty years, when adultery is supposed to have been common (e.g., Burrows and Spiro 1957). It makes the gonnwar relationship, which presently precedes about half of all Ifaluk marriages, ${ }^{7}$ a dangerous game. In the gornwar, after courting her with gifts of food, tobacco and clothes, a man is supposed to sneak into his lover's house at night, crawl under her mosquito netting, spend the night and sneak back home before dawn (ibid., pp.291-2). In spite of the risk he ran, a gonwwar suitor was not assured a wife unless, having accomplished all this, he won her parents' consent.

Finally, to individual acts of sorcery and border conflicts, Cantova (1728:242-3) added brief notes on intervillage warfare (by 'single combat') and clan battles (in which 'the "troops" come together, each of the two parties form [ing] squadrons of three ranks') in his descriptions of conflict on low Caroline Islands. On Ifaluk, the latter are no longer recalled.

\section{CONCLUSIONS}

Sharing is, and always has been, an important ethic in Ifaluk. The flow of resources between Ifaluk and Yap (e.g., Lessa 1950; Lingenfelter 1975), between Ifaluk and nearby islands (e.g., Alkire 1965), among Ifaluk chiefs and commoners (e.g., Betzig 1988a), and among Ifaluk commoners themselves (e.g., Betzig and Turke 1986; Betzig 1988b), has sometimes been essential to survival. But on Ifaluk, as everywhere else, these resources were not always sought or offered amicably. Between roughly equal powers, that is, between Ifaluk and nearby atolls, or between individual Ifaluk commoners, violence took the form of wars in the first case, and of property destruction, sorcery and murder in the latter. Between unequal powers, that is between Ifaluk and Yap, or between Ifaluk commoners and chiefs, violence took the form of sorcery and perhaps a war of conquest in the first case, and of property destruction, sorcery and maybe exile in the latter. Motives for these conflicts always included land and resources; women were a motive at least for conflict on Ifaluk itself; early sources add the possible motive of political ambition. How often such motives were expressed in violence is difficult to determine. Some early European sources (e.g., Lütke 1835) suggest that low Caroline islands were characterized by peace; others (e.g., Cantova 1728) suggest that violent conflict was not uncommon. Evidence both within (e.g., Firth 1959) and across 
cultures (e.g., Knauft 1987) suggests the possibility that the frequency of violent conflict might increase, rather than decrease, as resources become scarce.

For whatever reasons, all of these kinds of conflict have declined over time, to the point that few cases can be recalled today. The things most effective in bringing about pacification have included European guns, Christianity and economic sanctions. The first missionaries to the Carolines brought Spanish soldiers; perhaps a critical mass of these men contributed to Christianity's success (see Cantova 1731-1734:269; Hezel 1983:54-8). Cantova managed to convert several hundred Ulithians before he was massacred after part of his party sailed away for supplies (Lessa 1966:6; Hezel 1983:54-8).

In the long run, though, the conversion of most Carolinians was accomplished. Of the tribute relationship between Ulithi and Yap, Lessa (1950a:50) wrote that

the weakening of relationships with Yap are due also to a change in attitude towards that island, for Ulithians are now predominantly Christians, and Yapese are still largely pagans ... The new religion has freed the bulk of the population from the fear of supernatural reprisals by Yap.

On Ifaluk, which has never in its history had a resident missionary, Christianity has had great success. In 1983, all but thirty-six holdouts, most of them of high status, spent every Sunday, and often other days, praying in a large thatch hut with a cross on the front. It seems possible that the egalitarian message in the New Testament may have been immediately popular among Carolinian commoners, and gradually accepted by Carolinian chiefs as their authority eroded under the force of other sanctions. Following Spanish, German and then Japanese guns, those sanctions took an explicitly economic form under the United States Trust Territory administration at the end of the second World War. It was the policy of the Kennedy presidency to foster Micronesian dependence on American dollars, which ensured military cooperation (e.g., Lutz 1980). Like the Christians who preceded them, representatives of U.S. administrations looked down on any form of caste discrimination.

Under the present circumstances, violent conflict in Ifaluk, and on other Caroline Islands, is nearly absent. Why violence is less frequent on some of these islands than on others, why conflict may be less frequent overall in the Carolines than in other cultures, and how ethics of cooperation are taught the children of these islands, all remain interesting questions.

\section{APPENDIX}

What follow are legends of wars between Ifaluk and three nearby low Caroline islands, Lamotrek, Faraulep, and Woleai. Each account begins with a synopsis of the version told to Burrows and Spiro in 1947 by their informants, Totogoeiti (Burrows and Spiro 1957:10-18). Our informant was Tarmai, a lifelong inhabitant of Ifaluk, and Wichimai's father.

\section{Lamotrek}

Of the three legendary wars recalled by Totogoeiti and Tarmai, the war with Woleai was first; the war with Faraulep was second; and the war with Lamotrek was the most recent. In Totogoeiti's version, the Lamotrek war began at Lamotrek's provocation. 'Long, long ago, the people of Lamotrek used to kill the Ifaluk people whenever a canoe from Ifaluk put in there.' In this case, all but one of the crew of a single Ifaluk canoe was slaughtered; the slaughter was found out; and the deaths were avenged (Burrows and Spiro 1957:13, 15). 
In Tarmai's version, the war began at the Ifaluk ubut's ('kings') instigation. A canoe came first from Lamotrek to visit Ifaluk. Mauch [Totogoeiti's 'Maur') told the men on it that he was sick, and that no one from Ifaluk was willing to nurse him. He told them to tell his best friend, a Lamotrek chief, to come care for him. They did; the Lamotrek chief came; and he nursed Mauch at Katelu (Ifaluk's men's house) until he could walk. When he left, Mauch told the Lamotrek chief that if any Ifaluk canoes should arrive at his island, he should kill the crewmen, to pay them back for their neglect when their king was sick. He also told him that a strange person ('Tunga' a cripple with a short torso and long legs) would be on the canoe, to spare him, and to use him to show off on Truk.

As the Lamotrek chief sailed away, Mauch assembled the people on Ifaluk. He sent a canoe of them, including Tunga and the 'best' captain on the island, to Lamotrek on what he knew to be a death errand. When they failed to return, he assembled crews to fill another two canoes, and sent them after the 'stuff' he said he'd wanted the first time. When these canoes came within sight of Lamotrek, the people lit big fires, luring them to a treacherous 'feast', which would have ended in their deaths. But when the Lamotrek canoes came out in greeting, a good friend of this Ifaluk captain wore a flower behind his right ear, which he switched back and forth to his left, as a silent warning not to come and eat. At this, the captain altered course, saying, 'Maybe we'll go first to Truk and come back'.

The two canoes looked for a Lamotrek canoe on Truk, found Tunga hidden in it, and then sailed back to Ifaluk. From this point, Tarmai's version agrees exactly with Totogoeiti's. In short, Mauch convened an assembly to prepare for war; the men made spears in preparation ('one man 20, another man 30 , another man $40^{\circ}$ [p.14]), and, by a combined frontal attack behind a smoke screen and surprise attack from the rear, the warriors from Ifaluk exterminated the entire population of Elato (whose citizens had fled there) and Lamotrek. One man and his sister were sent from each Ifaluk clan to repopulate; since then, 'Lamotrek people are just same as Ifaluk people' (p.15). Tarmai adds that Mauch, as in the legends below, did not fight in the war himself, but stayed behind with a few other men to stand guard on Ifaluk. Mauch's sons, however, did not stay behind; they were killed in the war.

\section{Faraulep}

In Totogoeiti's version, people of one of Faraulep's two inhabited islets killed the people from the other in a surprise attack while they were torchlight fishing; the sole survivor, Nagelimwara, from the group attacked, avenged it; and men in a canoe from Ifaluk which eventually came along found only that one man, killed him, and then repopulated Faraulep with members of their own clans.

According to Tarmai, after winning their war with Woleai, the people if Ifaluk wanted to conquer all. But, as it turns out, one Ifaluk man managed to conquer Faraulep alone. This man Uwelibwe, from Hofalu clan, had married and gone to live with a woman from Faraulep. One day Uwelibwe sent his wife to tell the people of the other islet, Pigue, that people from their own were coming to kill them. She came back and reported they were ready for war. So they were: while men of Uwelibwe's islet were fishing by torchlight, men of Pigue attacked them and killed all of their women and children. Uwelibwe, who anticipated this attack, hid safely in the men's house (though his wife was killed!). The next day, he loaded his canoe with haingie, the hard wood sticks still used to pound coconut husk fiber for rope, and paddled to Pigue, where he told the men he'd found a big school of fish, and advised them to dive into the water to get them. They did; and as they came up for air, Uwelibwe did every one of them in with his haingie. He went back to Pigue and killed everybody, all the old men, women and children who had stayed behind.

At this point Mailias, the great Ifaluk warrior who directed the attack against Lamotrek (in both Totogoeiti's and Tarmai's legends), sailing from Lamotrek to Woleai, met Uwelibwe, sailing back to Ifaluk, on the open water. Uwelibwe told Mailias the story of how he had single-handedly wiped out the people of Faraulep; and said he was going to Ifaluk to get reinforcements to repopulate. Mailias said, 'No, I'll go to Ifaluk and get Hofalu clanspeople; you got to Woleai to pick up members of Kalingawoleai. When you get to Woleai, be sure to wait three weeks for good winds; I'll meet you then in Faraulep'. Uwelibwe agreed. Mailias did sail to Ifaluk, then, picked up his wife and children, and took them straight 
back to Faraulep. Three weeks later, Uwelibwe sailed in after sunset. Mailias canoed out to greet them, advising 'stay in your canoes tonight; I'll get you in the morning'. But after Uwelibwe and the Woleaians were asleep, Mailias untied their anchor, and their canoe drifted across the lagoon close to Pigue. Uwelibwe could hear the breakers in his sleep, and wondered where they were. In the morning, Mailias was waiting for them on Pigue. Before they landed, he said, 'This small part of Pigue is yours; all the rest of Faraulep is mine!' That's why Hofalu and Kalingawoleai are big clans even now on Faraulep. They got there first.

\section{Woleai}

According to Totogoeiti, this war began when Mauch, of the Lamotrek legend, who had married a beautiful Woleaian woman, was beaten and left for dead by jealous Woleaian men. After being revived by another woman, who emptied her bladder on him, Mauch made the 30 mile trip back to Ifaluk on a piece of driftwood. He was brought to the men's house (Katelu), took off his loincloth, and admonished the men that as his penis pointed to Woleai, they would have to make war there. 'The men of Ifaluk went to work and made spears (kobai) many spears for each man. They went to Woleai in many canoes - two hundred, three hundred' (Burrows and Spiro 1957:11). By various tricks, these men wiped out every Woleaian woman, man and child, with the exception of Mauch's wife and son. The conquerors sailed back to Ifaluk, where Mauch convened them and named one man from every Ifaluk clan to return to Woleai, along with his sisters and sons, as a chief. 'These people, with Mauch's wife and son, repopulated Woleai. So now when Ifaluk men go to Woleai, there is no more fighting. It is as if the two islands were all one place' (p.12).

According to Tarmai, Totogoeiti's legend of extermination is right in every detail. He differs, however, on the matter or repopulation. In Tarmai's version, men from different Ifaluk clans claimed Woleai land in the war, and then brought people from their own clans to settle and repopulate it. Tarmai pointed out that Mengaulufach clan, now the biggest on Woleai, got the biggest share of Woleaian land and reef. He recalled the following legend to account for that fact.

A Mengaulufach warrior was out collecting ut (a fragrant flowering tree) after the battle; meanwhile, other warriors claimed Woleaian land and reef for themselves. The Mengaulufach warrior returned from collecting flowers, realized the situation, and waited for night to fall. During the day, after the battle, others had staked their claims with sticks wrapped with fresh, green coconut leaves. That night, this warrior took old, brown palms and wrapped them around sticks of his own. In the moming. he pointed out that as his leaves were older, his claim was stronger, and they gave in!

Tarmai added that this, like every other warfare legend, is meant to account for the distribution of clans in the atolls now. On modem Woleai, each of the Ifaluk clans exists, with Mengaulufach the most numerous. Of the repopulating clans Totogoeitis' lists (p.12), only Kalingawoleai ('clan of Woleai', spelled 'Kaliangaluiela' on Totogoeiti's list) is not on Ifaluk now. Tarmai added one more fact to this legend: as in the Lamotrek war, Mauch did not participate, but stayed behind with a few other men to guard home.

\section{ACKNOWLEDGEMENTS}

We thank the people of Ifaluk, including Hasefalgar, Fagolimul and especially Tarmai, for their generous cooperation in letting us know about conflict. We are very grateful, too, to William Lessa for sending copies of his own work and for commenting on ours; and to Father Francis Hezel for sending his translations of Cantova's letters. This study would not have been possible without an NIMH training grant awarded through the University of Michigan Department of Psychology, a grant from the National Geographic Society, and a grant from the Wenner-Gren Foundation. 


\section{NOTES}

1. As of 1987 , Ifaluk visitors to Yap, especially chiefs, were required to bring a gift of two or three lava lavas to Gachpar village in Gagil; in retum, they were given breadfruit and taro, as they have always been. In 1985 , when a Korean ship landed off Ifaluk, they were required to give Yap a portion of the ensuing wealth.

2. It is tempting to speculate that the common Yapese tradition of patriliny and the outer islands tradition of matriliny might be related to this migration of women. As Dickemann (1979) has dernonstrated, inheritance in other 'empires' has followed this pattern, with sons being favored among polygynous overlords, and daughters preferred, or at least not disinherited, among more monogamous subordinates. Such an inheritance pattem, Dickemann suggests, should increase the production of children and grandchildren.

3. Burrows and Spiro (1957:16-18) also repon that Satawal, initially uninhabited, is supposed to have been settled by people from Ifaluk who went to repopulate Lamotrek. Satawalese, though, presently speak a dialect almost unintelligible to speakers of the 'Woleaian' spoken on Woleai, Eauripik, Ifaluk, Faraulep, Elato and Lamotrek (see Sohn and Tawerilmang 1976); Satawal clans differ as well.

4. It is interesting that Father Walter found visiting men of rank were carried in litters, "without letting them set foot on the ground until they took them to the hut prepared for them' (in Cantova 1731-1734:275).

5. Traditionally, the highest ranking thing on Ifaluk has been an inanimate object. In 1987, members of Hofalu clan were considering reviving an old tradition of asking Woleai chiefs to help settle upon a successor to the ubut who had died almost a year earlier. As part of this tradition, these chiefs are supposed to have beseeched the 'Ifaluk flag' (waliwol) to watch the new chief carefully and, should he misbehave, to 'strike him dead!' The Ifaluk flag is a carved wooden phallus hung from the front of Katelu, the men's house, the most imposing structure on Ifaluk. This flag alone, then, held a sanction over the highest Ifaluk chief (cf. Lessa 1980).

6. That chiefs of Saufelachig rather than Hofalu should be given tribute is puzzling if people of rank are supposed to receive commensurate privileges. Another Ifaluk legend addresses this problem. According to Tarmai, Saufelachig was once the highest ranking Ifaluk clan, its head being the ubul or 'king'. But one Saufelachig king loved his Hofalu son so much that, contrary to matrilineal prescription, he had his son succeed him. Since then, Hofalu has been the highest clan. This makes sense, too, of the fact that Saufelachig still owns Ella (Ifaluk's large uninhabited islet), along with much of Ifaluk's reef (Saufelachig being the only Ifaluk clan to own reef), together with the northern half of one of Ifaluk's two inhabited islets, Falachig (for living on which residents of Falachig village pay tribute or 'rent'). Tarmai and others added that in the old days, when Saufelachig was most high, the highest ranking wornan of that clan would choose among all of the men of Falachig village one to be her husband. In couring her, these men would bring gifts of breadfruit, tuba (palm wine) and fish. Now, the courtship and marriage no longer take place. Still, the tradition is preserved as Falachig men bring tribute to the Saufelachig chief.

7. The primary source in these paragraphs is the second author of this paper, Santus Wichimai, a lifelong Ifaluk resident, who is currently its representative in the Senate of Yap State, of the Federated States of Micronesia. Many of Ifaluk's residents, including Hasefalgar, Fagolimul and especially Tarmai, consulted with Wichimai on these important subjects.

\section{REFERENCES}

ALEXANDER, R.D. 1979. Darwinism and Human Affairs. Seattle: University of Washington Press.

ALKIRE, W.H. 1965 Lamotrek Atoll and Inter-Island Socioeconomic Ties. Urbana: University of Illinois Press.

1974. Land Tenure in the Woleai. In H.P. Lundsgaarde (ed.), Land Tenure in Oceania. Honolulu: University of Hawaii Press.

BARRY, H. AND A. SCHLEGEL. 1982. Codes on Contributions by Women to Subsistence. Ethnology 21:165-88.

BATES, M. 1956. Ifaluk: Paradise in the Pacific . National Geographic.

BATES, M. and D. ABBOTT. 1958. Coral Island. New York: Scribner's. 
BEAUCLAIR, I. de 1963. Black Magic on Ifaluk . American Anthropologist 65:388-9.

1964. Caste and Class on Yap. Bulletin of the Institute of Ethnology, Academia Sinica 14.

BETZIG, L.L. 1982. Despotism and Differential Reproduction: A Cross Cultural Correlation of Conflict Asymmetry, Hierarchy and Degree of Polygyny. Ethnology and Sociobiology 3:209-21.

1986. Despotism and Differential Reproduction. Hawthome, N.Y.: Aldine-de Gruyter.

1988a. Redistribution: Equity or Exploitation? In L. Betzig, M. Borgerhoff Mulder and P. Turke (eds), Human Reproductive Behaviour. Cambridge: Cambridge University Press.

1988b. Adoption by Rank on Ifaluk. American Anthropologist 90:111-19.

1991. Of Human Bonding. In A. Hardcourt and F. de Waal (eds), Cooperation in Conflict in Animals and Humans. New York: Oxford University Press (in press).

BETZIG, L. and P. TURKE. 1985. Measuring Time Allocation: Observation and Intention. Current Anthropology 26:647-50.

1986. Food Sharing on Ifaluk. Current Anthropology 27:397-400.

BURROWS, E.G. 1949. Report of the Coordinated Investigation of Micronesian Anthropology. Washington, D.C.: Pacific Science Board.

BURROWS, E.G. and M.E. SPIRO. 1957. An Atoll Culture: Ethnography of Ifaluk in the Central Carolines. Westport, CT.: Greenwood Press.

CANTOVA, J.A. 1728. Lettre du P. Jean Cantova, March 20, 1722. Lettres Edifiantes et Curieuses 18:188-247. Translation courtesy of Father Francis Hezel.

1731-34. The Discovery and Description of the Garbanzos Islands. Bolétin de la Sociedad Geografica de Madrid 10:263-79. Translation courtesy of Father Francis Hezel.

CHAGNON, N.A. 1979. Is Reproductive Success Equal in Egalitarian Societies? In N.A. Chagnon and W. Irons (eds), Evolutionary Biology and Human Social Behavior, pp.374-401. North Scinate, MA.: Duxbury Press.

DAMM, H. et al. 1938. In G. Thilenius (ed.), Ergebnisse der Südsee Expedition 1908-1910. Hamburg: Friederichsen, du Gruyter and Co. Human Relations Area Files translation.

DARWIN, C. 1871. The Descent of Man and Selection in Relation to Sex. New York: Modern Library.

DICKEMANN, M. 1979. Female Infanticide, Reproductive Strategies and Social Stratification: A Preliminary Model. In N.A. Chagnon and W. Irons (eds), Evolutionary Biology and Human Social Behavior, pp. 321-67. North Scituate, MA.: Duxbury Press.

FIRTH, R.B. 1959. Social Change in Tikopia. London: Allen and Unwin.

GLADWIN, T. 1970. East is a Big Bird: Navigation and Logic on Puluwat Atoll. Cambridge: Harvard University Press.

GLADWIN, T. and W. SARASSON. 1953. Truk: Man in Paradise. Honolulu: University of Hawaii Press.

HEZEL, F. 1983. The First Taint of Civilization: A History of the Caroline and Marshall Islands in Pre-Colonial Days, 1521-1885. Honolulu: University of Hawaii Press.

HURTADO, A.M. 1985. Women's Subsistence Strategies Among Ache Hunter- Gatherers of Paraguay. Ph.D. dissertation, Department of Anthropology, University of Utah.

KNAUFT, B. 1987. Reconsidering Violence in Simple Human Societies. Current Anthropology 28:457-99.

KRÄMER, A. 1932. Truk. In G. Thilenius (ed.), Ergebnisse der Südsee Expedition 1908-1910. Hamburg: Friederichsen, de Gruyter and Co. Human Relations Area Files translation.

1937. Lamotrek-Gruppe, Oleai, Feis. In G. Thilenius (ed.), Zentralkarolinen, 1. Hamburg: Friederichsen, de Gruyter and Co. Human Relations Area Files translation.

LESSA, W.A. 1950a. Ulithi and the Outer Native World. American Anthropologist 52:27-52.

1950b. Ethnography of Ulithi Atoll. CIMA report. Washington D.C.: Pacific Science Board.

1961. Sorcery on Ifaluk. American Anthropologist 63:817-20. 
1962. An Evaluation of Early Descriptions of Carolinian Culture. Ethnohistory 9:313-403.

1966. Ulithi: A Micronesian Design for Living. New York: Holt, Rinehart and Winston.

1975. The Portuguese Discovery of the Isles of Sequeira. Micronesica 11:35-70.

1980. More Tales from Ulithi Atoll. Berkeley: University of California Press.

LESSA, W.A. and C.G. VELEZ-I. 1978. Bwang, a Martial Art of the Caroline Islands. Micronesica 14:139-76.

LINGENFELTER, S.G. 1975. Yap: Political Leadership and Culture Change in an Island Society. Honolulu: University of Hawaii Press.

LOW, B.S. 1988. Measures of Polygyny in Humans. Current Anthropology 29:189-94.

LUTKE, F. 1835. Voyage Autour du Monde ... Paris: Firmin Didot. Reprinted in 1971 in Bibliotheca Australiana No. 58, 59. New York: Da Capo.

LUTZ, C. 1980. Emotion Words and Emotional Development on Ifaluk Atoll. Ph.D. dissertation, Department of Anthropology, Harvard University.

1982. The Domain of Emotion Words on Ifaluk. American Ethnologist 9:113-28.

1988. Unnatural Emotions. Chicago: University of Chicago Press.

MANSON, J. and R.W. WRANGHAM. 1991. Intergroup Aggression in Chimpanzees and Humans. Current Anthropology 32: (in press).

MAYNARD SMITH, J. and G. PARKER. 1976. The Logic of Asymmerric Contests. Animal Behaviour 24:159-74.

MONTAGU, A. 1976. The Nature of Human Aggression. New York: Oxford.

MURDOCK, G.P. 1967. Ethnographic Atlas. Pittsburgh: HRAF Press.

SAHLINS, M.D. 1972. Stone Age Economics. Hawthorne N.Y.: Aldine-de Gruyter.

SERVICE, E.R. 1975. Origins of the State and Civilization. New York: Norton.

SOHN, H. and A. TAWERILMANG. 1976. Woleaian-English Dictionary. Honolulu: University of Hawaii Press.

SPIRO, M.E. 1942. Report of the Coordinated Investigation of Micronesian Anthropology. Washington D.C.: Pacific Science Board.

1950. The Problem of Aggression in a South Sea Culture. Ph.D. dissertation, Department of Anthropology, Northwestern University.

1952. Ghosts, Ifaluk and Teleological Functionalism. American Anthropologist 54:497-503.

TURKE, P.W. 1985. Tests of Economic and Darwinian Hypotheses of Fertility Determinants on Ifaluk and Yap. Ph.D. dissertation, Department of Anchropology, Northwestern University.

1989. Evolution and the Demand for Children. Population and Development Review 15:61-90. 